\title{
Female Flânerie in Dorothy Richardson's Pilgrimage
}

\author{
Pilar Hidalgo \\ University of Málaga
}

\begin{abstract}
I take as a starting point the often-repeated assertion that the literature of modernity describes the experiences of men, and the long-established connection between the public sphere and the city in modernity. From Baudelaire's definition of the flâneur to Benjamin's elaboration of the concept, it is inevitable that some contemporary critics should have explored the role (if any) of the flâneuse in modernism. Dorothy Richardon's Pilgrimage presents an intriguing case of female flânerie. The potent Woolfian image of the room as the space of female creativity has obscured the equally potent image of the street (specifically London street) as the site of female empowerment. In Pilgrimage, the pervasive questioning of men's values, men's culture and men's language is bound up with Miriam Henderson's having the freedom of the London streets.
\end{abstract}

"In the flâneur the joy of watching is triumphant"

Walter Benjamin

That the literature of modernity describes the experience of men has become a commonplace of gender-conscious criticism. Central to that experience is the modern city, with its streets and arcades where the anonymous hero strolls at leisure. As Janet Wolff puts it: "The flâneur is the modern hero; his experience ... is that of a freedom to move about in the city, observing and being observed, but never interacting with others. A related figure in the literature of modernity is the stranger... These heroes of modernity thus share the possibility and the prospect of lone travel, of voluntary uprooting, of anonymous arrival at a new place. They are, of course, all men" (Wolff 39).

The flâneur or stroller as first defined by Baudelaire in "The Painter of Modern Life" is intimately connected with the conditions of life in the modern city. Giuliana Bruno and other film theorists have detected an element of flanerie in Barthes' description of the pleasures of the cinema: "Idleness, leisure, the inoccupation of bodies, describe the "cinema situation." A last step in a perceptive trail that takes one from street to street, 
cinema inhabits flanerie ... The perceptual link between flânerie and cinema concerns the "montage" of images, the spatio-temporal juxtaposition, the obscuration of the mode of production, the "dream web," and the "physiognomic" impact-the spectatorial reading of bodily signs" (Bruno 10).

It is not difficult to relate the concept of the flâneur as archetypically modern and of the city as his natural milieu to the representation of the city in modernist literature. Jean Radford has been one of the first to argue for the significance of Miriam Henderson's walking the streets of London in Pilgrimage (especially in the volumes between The Tunnel and Clear Horizon), and to connect this activity with "an actual enlargement in women's sphere of movement during the period 1896-1908. Improvements in the policing and lighting of central London, the extension of the underground system, bycicle and loosening codes of respectability, meant greater freedom for the middle class woman than ever before" (Radford 53).

Obviously, even in these improved conditions, gender limits the options of the wouldbe female flâneur; as Bruno points out, "a male loiterer is a flâneur; a female is a streetwalker" (Bruno 13). The dangers attending women walking outdoors on their own are very present in nineteenth-century fiction. We have only to think of the shocked reaction to Elizabeth Bennet's walking across the fields to visit her sick sister, or of Harriet Smith in Emma assailed by a party of gipsies on the Richmond road, or more to the point since it takes place in a city; of Lucy Snowe's being accosted by two men on her first night in Villette. All of which makes Miriam Henderson's freedom of movement in London more significant.

The potent Woolfian image of the room as the space of female freedom and creativity has tended to obscure the equally potent image of the street (specifically the London street) as the site of female empowerment. And we should keep in mind that Richardson, and to a lesser extent Woolf, challenge the construction of the city as a wasteland in male modernism. Radford accounts for the difference in terms of class and gender, particularly gender: "The conservatism of the English past, the text indicates, meant only restriction, dependence, imprisonment. In contrast, London is imaged as positive, enabling" (Radford 35).

The fact that the city of modernity meant different things to men and women is but one thread in the complex web of oppositions embedded in Pilgrimage. The text foregrounds the differences in men and women's language, attitudes, ways of thinking, and feelings. Pilgrimage has usually been approached as the formless recording of transient encounters and impressions, the chaotic rendering of individual consciousness, the archetypal product of the female aesthetic. This is to be expected in a critical practice that privileges form over content. I find it more challenging to foreground the intellectual underpinnings of its innovative technique and to take as a starting point what Hanscombe says about Richardson's aims: "She is one of the very few to attempt the very complex task of explicating a feminist world-view at the same time as developing a feminist aesthetic in a work of imaginative literature. The attempt may be thought misguided, even offensive, but that Pilgrimage enacts such an attempt is fundamental to its stature" (Hanscombe 166). 
The contrast between the social documentation of the typical Edwardian novel and the spareness and symbolic reach of some modernist fiction has become a cliché. It is ironical that Hypo Wilson, fictional embodiment of one of the representatives of that kind of novel, should advise Miriam Henderson to write her own version of the genre: "You've an extraordinarily rich life in that Wimpole Street of yours. You have in your hands material for a novel, a dental novel, a human novel and, as a background, a complete period, a period of unprecedented expansion in all sorts of directions ... You ought to document your period" (IV 397, emphasis added). Which Richardson does, though not in the way recommended by Wilson/Wells.

When Miriam Henderson arrives in London in the 1890 s to work as a dental assistant and find lodgings in a Bloomsbury attic, she is truly a New Woman. Despite her poverty and drudgery (she makes a pound a week), her experience beginning with The Tunnel (1919) radiates happiness and excitement and is inextricably bound up with her living in London: "that feeling when you live right in London, of being a Londoner, the thing that made it enough to be a Londoner, getting up in London; the thing that made real Londoners different from any one else, going about with a sense that made them alive. The very idea of living anywhere but in London produced a blank sensation in the heart" (II 265-66, Richardson's emphasis).

If Miriam is one of the first women in fiction to walk extensively about the modern city, her wanderings are different from those of the male flâneur. She moves about freely, she observes and is observed, she is protected by the anonymity of the crowd and she is on the margins of society. But her leisure and her combination of involvement and noninvolvement (both characteristics of the flaneur) hinge on gender. For one thing, her leisure depends on her not being married, on her mother being dead, and on her resisting the emotional demands made on her by other women. A good example of the latter is her relationship with Eleanor Dear, and Miriam's resentment when Mr Taunton tries to make her take on the responsibility of looking after the destitute and ill young woman ("Domestic work and the care of the aged and the sick-very convenient-all the stuffy nerve-racking never ending things to be dumped on to women- who are to be openly praised and secretly despised for their unselfishness," II 279).

The flip side of Miriam's flânerie is marked by her relationships with men. It is part of the documentary (in a non-Wilsonian sense) side of the novel that a woman of Miriam's (and Richardson's) generation should have identified freedom and intellectual independence with men. When Vita Sackville-West's Lady Slane (All Passion Spent) dreams at seventeen of becoming a painter, she sees herself travestied into a young man. Miriam does not play with the outward signs of her sex, but when she goes with Mendizabal to a café, the typical haunt of the continental flaneur, she lives the experience as if she were a man: "She was there as a man, a free man of the world, a continental, a cosmopolitan, a connoisseur of women" (II 394). On her walk home after attending one of the many lectures mentioned in the novel (on philosophy, science, foreign literatures, socialism, Zionism, etc.), Miriam reflects that the things of the mind that so engross her had passed her sisters by, and comes to the conclusion that: "It was clearly not her fault that she had a masculine mind" (III 236). So that despite the searching critique of men's values, attitudes and language presented through the medium of Miriam's consciousness 
in Pilgrimage, it is presumably her man's part which allows her to stroll along Oxford Street thinking about Ibsen's Brand (II 384).

Her partial identification with men notwithstanding, Miriam's story in Pilgrimage is punctuated by her successive rejection of possible lovers and husbands. ${ }^{1}$ In a way, her ultimate rejection of men is the result of her awareness that her "masculine" freedom is incompatible with a permanent association with a man. She not only rejects, but is rejected for reasons that would not be out of place in the world of Victorian fiction. At the end of Interim Dr von Heber goes back to Canada without proposing to Miriam, because of comments made by Mendizabal. And March Moonlight, the last novel in the sequence (or chapter in the novel Pilgrimage, as Richardson would have it) ends with Miram being rejected by her Quaker friends and by the man she had finally made up her mind to marry because she had felt obliged to tell him about her affair with Hypo Wilson. Of course Pilgrimage eludes closure (just as it eludes "telling" or "showing" any event in a straightforward manner); the last page contains the only precise date in the sequence, autumn 1915, when Miriam is writing what would eventually become Pilgrimage, whose first volume or chapter, Pointed Roofs, was published in 1915.

To take up again the dichotomy involvement/non-involvement typical of the flaneur, Miriam's flanerie emphasizes the latter in a rather striking manner. Her non-involvement is not only a question of keeping men at bay in order to preserve her autonomy; she also remains uninvolved in what one would have expected to be a key issue for an emancipated working woman at the turn of the century: the suffrage campaign. Although her intense friendship with Annabel looms large in the later novels, Miriam does not take part in any suffragist activity, and does not understand why Annabel does: "She remembered with a pang of dismay that the march of the militants on the House of Commons had been fixed for tonight. .." (IV 342). When she visits Annabel at Holloway prison she is horrified by the conditions in which the suffragists are held, but earlier, during a conversation with Hypo Wilson on female suffrage, she had said: "I don't want a vote. I want to have one and not use it. Taking sides simply annihilates me" (III 394).

As so often in Pilgrimage, there is an autobiographical side to Miriam's fear of involvement. In a letter to Rose Odle, Richardson's sister-in-law and literary executrix, Veronica Grad (the real-life Annabel) puts it this way: "Dorothy never paid any prices. She took an avid interest in other people, their lives, their misfortunes, their successes, but she never-looking back I see-gave either sympathy or help—or let herself become in any way involved-I am not thinking only of myself" (quoted in Hanscombe 179).

The fact that Miriam Henderson does not get involved in any of the causes she is acquainted with in her busy London life (feminism, socialism, Zionism, anarchism) and that, in true flaneur fashion, she seems to derive pleasure from watching, should not obscure the significance of Pilgrimage as a millstone in the fictional recording of women's history. The widening range of experience open to educated urban women at the turn of the century is reflected in even such a traditional aspect as the choice of a male partner: Canadian doctor, Russian Jew, married, "progressive" English writer, and French defrocked priest. As late as 1982 Gloria Fromm could complain that: "No one has paid sufficient attention to the powerful feeling in Pilgrimage for the sheer overwhelming presence of phenomena and their impact on a receptive sensibility" (Fromm 177). She also 
emphasizes the contribution that the authenticity of the period detail makes to the texture of the novel. I would like to take this issue a bit further and argue that "texture" (transient impressions, phenomena) and "document" (changes in women's daily lives) are bound up in Pilgrimage.

Insofar as Miriam's life in London and her consciousness are historically new and made possible by the conditions of modern life, we have to qualify the statement that "the literature of modernity presents the experience of men." Throughout Pilgrimage, the radical difference between men and women becomes a connecting thread. Miriam's unashamed essentialism covers both life (thus on her landlady Mrs Bailey: "where did women find the insight into personality that gave them such extraordinary prophetic power?," III 37) and literature (on Anna Karenina: "The story of woman told by a man with a man's ideas about people," III 59). Although most of the books Miriam reads are by men, the references to women writers also betray a fundamental awareness of gender difference. Miriam famously asserts that George Eliot "writes like a man" (IV 240); she quotes (without giving title or author) Olive Schreiner's The Story of an African Farm when Mrs Bailey tells her that the Canadian doctor has gone away because of false rumours about her and Mendizabal: "A woman must march with her regiment; if she is wise she does" (II 434-5).

The question of whether Miriam Henderson's strolling makes her a flâneuse $e^{2}$ or whether the gender inscription in modernism renders that impossible is perhaps less interesting than whether we can posit the presence of specifically female flânerie in Pilgrimage. Miriam Henderson's faculties go beyond the activity of watching and "botanizing on the asphalt" that Benjamin saw as typical of the (male) flaneur. At the end of the novel Miriam (who does far less strolling in the last volumes of the sequence) is about to start writing Pilgrimage, just as at the end of To the Lighthouse Lily Briscoe finishes her picture. The connections and disconnections of female modernism belong in another narrative. Let me end mine by quoting from Virginia Woolf's Diary (Friday, 28 November, 1919): “Today, bearing K(atherine) M(ansfield) in mind, I refused to do Dorothy Richardson for the Supt. The truth is that when I looked at it, I felt myself looking for faults; hoping for them. And they would have bent my pen, I know. There must be an instinct of self-preservation at work. If she's good then I'm not" (Woolf 315 ).

\section{Notes}

1. On the role of men in Pilgrimage, see Gloria G. Fromm, "What Are Men to Dorothy Richardson?," Women and Literature 2 (1982): 168-88.

2. Cf. Rachel Bowlby, "Walking, Women and Writing: Virginia Woolf as Flâneuse," in Isobel Armstrong ed., New Feminist Discourses (London: Routledge, 1992), pp. 26-47. 


\section{Works Cited}

Bruno, Giuliana. "Streetwalking around Plato's Cave," Unpublished paper presented at the Seminar on Feminist Theory/Film Theory, UMM, Valencia, Spain, July 8-12, 1991.

Fromm, Gloria G. "What Are Men to Dorothy Richardson?" Women and Literature 2: 168-88. Hanscombe, Gillian E. The Art of Life: Dorothy Richardson and the Development of Feminist Consciousness. London: Peter Owen, 1982.

Radford, Jean. "Coming to Terms: Dorothy Richardson, Modernism, and Women." News from Nowhere 10 (1989): 25-36.

. Dorothy Richardson. New York: Harvester Wheatsheaf, 1991.

Sackville-West, Vita. All Passion Spent. 1931. London: Virago, 1987.

Wolff, Janet. Feminine Sentences: Essays on Women and Culture. Cambridge: Polity Press, 1990. Woolf, Virginia. The Diary of Virginia Woolf. Volume I: 1915-1919. Harmondsworth: Penguin, 1977-79.

All references to Pilgrimage are to the 1979 Virago edition. The numbers in brackets (II 58) indicate the volume and page number.

\section{Departamento de Filología Inglesa UNIVERSIDAD DE ALICANTE}

\section{Working Papers}

A Profile of the Motivation of Spanish Pre-University

Students in the Learning of English

José Castro Calvín

The Dichotomy between Public and Private in the

British Intellectuals of the $30 \mathrm{~s}$

Silvia Caporale Bizzini

Series edited by José Mateo Martínez, Celia Rico Pérez, and M. Carmen África Vidal 